\title{
Gambaran histopatologik ginjal wistar yang diberi ekstrak binahong pasca pemberian gentamisin
}

\author{
${ }^{1}$ Zularsil F. W. Rajak \\ ${ }^{2}$ Lily Loho \\ ${ }^{2}$ Poppy Lintong
}

\author{
${ }^{1}$ Kandidat Skripsi Fakultas Kedokteran Universitas Sam Ratulangi Manado \\ ${ }^{2}$ Bagian Patologi Anatomi Fakultas Kedokteran Universitas Sam Ratulangi Manado \\ Email: zularsilrajak21@gmail.com
}

\begin{abstract}
Kidney damage can be caused by many things, such as hypovolemia, sepsis, acute glomeluronefritis, rhabdomyolysis and drugs (gentamicin and NSAID). Gentamicin is an broad spectrum antimicrobial with high toxicity. Gentamicin is an aminoglycoside antibiotic known to be toxic to the kidneys and the side effects that gentamicin cause are renal tubular damage. There are many kinds of herbal plant in Indonesia with benefit, one of them is the binahong plants. Binahong (Anredera cordifoli (Ten) Steenis), has a high antioxidant that is equal to $9.614 \%$ of the compound flavonoid..$^{5}$ Antioxidant contained in binahong leaves can be said as nefroprotective on kidney function. This study aims to reveal the renal histopathologic of wistar rat that have administered binahong extract after gentamicin administration. This study was an experimental study using 25 wistar rats that were divided into 5 groups. Group A is the negative control group (terminated the 7th day), while group B, $\mathrm{C}, \mathrm{D}$ and $\mathrm{E}$ (the treatment group) were administered gentamicin $0.3 \mathrm{ml} /$ day for 6 days. After administration of gentamicin, group B immediately terminated (day 7), group C were administered $50 \mathrm{mg} /$ day of binahong extratct for 3 days (terminated on day 10), group D were administered $100 \mathrm{mg}$ /day of binahong extract for 3 days (terminated on day 10), group E were administered gentamicin for 6 days (terminated on day 10). The results showed that the renal histopathological of wistar rats group that were administered gentamicin for 6 days, showed swelling and necrotic tubular epithelial cells. Wistar rats group that were administered of binahong showed regeneration of renal tubular epithelial cells. Conclusion: The administration of Gentamicin with toxical dose or $0.3 \mathrm{ml} /$ day for 6 days showed acute tubular necrosis. Regeneration of renal tubular epithelial cells is better in the group that were administered binahong extract than the group that were administered pellets. Renal histopathologic of wistar rats at administration of binahong extract with dose of $100 \mathrm{mg}$ are better compared to $50 \mathrm{mg}$.
\end{abstract}

Keywords: gentamicin, binahong extract, histopathologogical image of wistar rat's kidney

\begin{abstract}
Abstrak: Kerusakan ginjal dapat disebabkan oleh berbagai hal, seperti hipovolemia, sepsis, glomeluronefritis akut, rabdomiolisis dan obat-obatan (Gentamisin dan NSAID). Gentamisin tergolong antibiotika (aminoglikosida) yang berspektrum luas dan memiliki toksisitas tinggi. Salah satu efek toksik dari gentamisin adalah menyebabkan kerusakan pada tubulus ginjal. Ada berbagai jenis tanaman herbal di Indonesia yang mempunyai khasiat, salah satunya adalah tanaman binahong, Tanaman binahong (Anredera cordifoli (Ten) Steenis), memiliki antioksidan yang cukup tinggi yaitu sebesar $9,614 \%$ senyawa flavonoid. Antioksidan yang terkandung dalam daun binahong dapat dikatakan sebagai nefroprotektif terhadap fungsi ginjal. Penelitian ini bertujuan untuk mengetahui gambaran histopatologik ginjal tikus wistar yang diberi ekstrak binahong pasca pemberian gentamisin. Penelitian ini merupakan penelitian eksperimental yang menggunakan 25 ekor tikus wistar yang dibagi dalam 5 kelompok. Kelompok A merupakan kelompok kontrol negatif (diterminasi pada hari ke-7),
\end{abstract}


sedangkan kelompok $\mathrm{B}, \mathrm{C}, \mathrm{D}$ dan $\mathrm{E}$ (kelompok perlakuan) diberi gentamisin $0,3 \mathrm{ml} / \mathrm{hari}$ selama 6 hari. Setelah pemberian gentamisin, kelompok B langsung diterminasi (hari ke-7), kelompok C diberi ekstrak binahong $50 \mathrm{mg} /$ hari selama 3 hari (diterminasi pada hari ke-10), kelompok D ekstrak binahong $100 \mathrm{mg} /$ hari selama 3 hari (diterminasi pada hari ke-10). kelompok E diberi gentamisin selama 6 hari (diterminasi pada hari ke-10). Hasil penelitian menunjukkan bahwa kelompok tikus yang diinduksi gentamisin selama 6 hari secara histopatologik memperlihatkan adanya pembengkakan dan nekrosis sel epitel tubulus. Kelompok tikus yang diberi ekstrak binahong menunjukkan regenerasi sel epitel tubulus ginjal Simpulan: Pemberian gentamisin injeksi dosis toksik yaitu 0,3 ml setiap hari selama 6 hari menunjukkan nekrosis tubular akut (NTA). Regenerasi sel epitel tubulus ginjal lebih baik pada kelompok yang diberi ekstrak binahong dibandingkan kelompok yang hanya diberi pelet. Gambaran histopatologik ginjal lebih baik pada pemberian binahong dengan dosis 100 $\mathrm{mg}$ dibandingkan dosis $50 \mathrm{mg}$.

Kata kunci: gentamisin, ekstrak binahong, gambaran histopatologik ginjal.

Kerusakan ginjal dapat disebabkan oleh berbagai hal, seperti hipovolemia, sepsis, glomeluronefritis akut, rabdomiolisis dan obat-obatan (Gentamisin dan NSAID) ${ }^{1}$. Gentamisin tergolong antibiotika (aminoglikosida) yang berspektrum luas dan memiliki toksisitas tinggi. Salah satu efek toksik dari gentamisin adalah menyebabkan kerusakan pada tubulus ginjal. $^{2}$ Ekskresi gentamisin hampir seluruhnya berlangsung melalui ginjal. ${ }^{3}$ Penggunan gentamisin yang tidak rasional dan tidak tepat dapat meningkatkan prevalensi patogen yang resisten terhadap beberapa obat. ${ }^{4}$

Tanaman herbal di Indonesia mempunyai banyak khasiat salah satunya adalah binahong. Tanaman binahong (Anredera cordifoli (Ten) Steenis), memiliki antioksidan yang cukup tinggi yaitu sebesar $9,614 \%$ senyawa flavonoid. ${ }^{5}$ Antioksidan yang terkandung dalam daun binahong dapat dikatakan sebagai nefroprotektif terhadap fungsi ginjal. Penelitian oleh Sukandar (2011) dilaporkan bahwa ekstrak daun binahong dengan dosis $150 \mathrm{mg} / \mathrm{kgBB}$ mampu memperbaiki fungsi ginjal pada tikus. ${ }^{6}$ Tujuan penelitian ini ialah untuk mengetahui gambaran histopatologik ginjal yang diberi binahong pasca pemberian gentamisin.

\section{METODE PENELITIAN}

Penelitian ini bersifat eksperimental laboratorik yang dilakukan pada bulan
September 2015 sampai Februari 2016 di Laboratoriun Patologi Anatomi Fakultas Kedokteran Universitas Sam Ratulangi Manado. Subyek penelitian ini ialah 25 ekor tikus wistar yang dibagi dalam 5 kelompok. Kelompok A (kontrol negatif), tikus tidak diberi perlakuan selama 6 hari dan diterminasi hari ke-7; kelompok $\mathrm{B}$, tikus diinduksi gentamisin selama 6 hari dan diterminasi hari ke-7; kelompok C, tikus diinduksi gentamisin selama 6 hari dilanjutkan dengan pemberian ekstrak binahong $50 \mathrm{mg}$ selama 3 hari dan diterminasi hari ke-10; kelompok $\mathrm{D}$, tikus diinduksi gentamisin selama 6 hari kemudian dilanjutkan dengan pemberian ekstrak binahong $100 \mathrm{mg}$ selama 3 hari dan diterminasi hari ke-10; Kelompok E, tikus diinduksi gentamisin selama 6 hari kemudian tidak diberi perlakuan selama 3 hari dan diterminasi hari ke-10. Tikus diotopsi dan organ ginjal diambil untuk dilakukan pemeriksaan histopatologi.

Ekstrak binahong yang digunakan adalah ekstrak daun binahong yang dibuat di Laboratorium Fakultas Matematika dan Ilmu Pengetahuan Alam Universitas Sam Ratulangi Manado. Dosis ekstrak binahong yang dipakai yaitu $50 \mathrm{mg} / \mathrm{tikus} / \mathrm{hari}$ dan $100 \mathrm{mg} /$ tikus/hari sedangkan dosis gentamisin ialah $0,3 \mathrm{ml} /$ hari. $^{7}$ 


\section{HASIL PENELITIAN}

\section{Kelompok A}

Jaringan ginjal tikus pada kelompok ini menunjukkan struktur dan sel-sel normal serta tidak ditemukan adanya kelainan. Tampak ginjal terdiri atas glomerulus dan dikelilingi oleh kapsul epitel berdinding ganda (kapsula Bowman), tubulus distal dan tubulus proksimal. (Gambar 1).

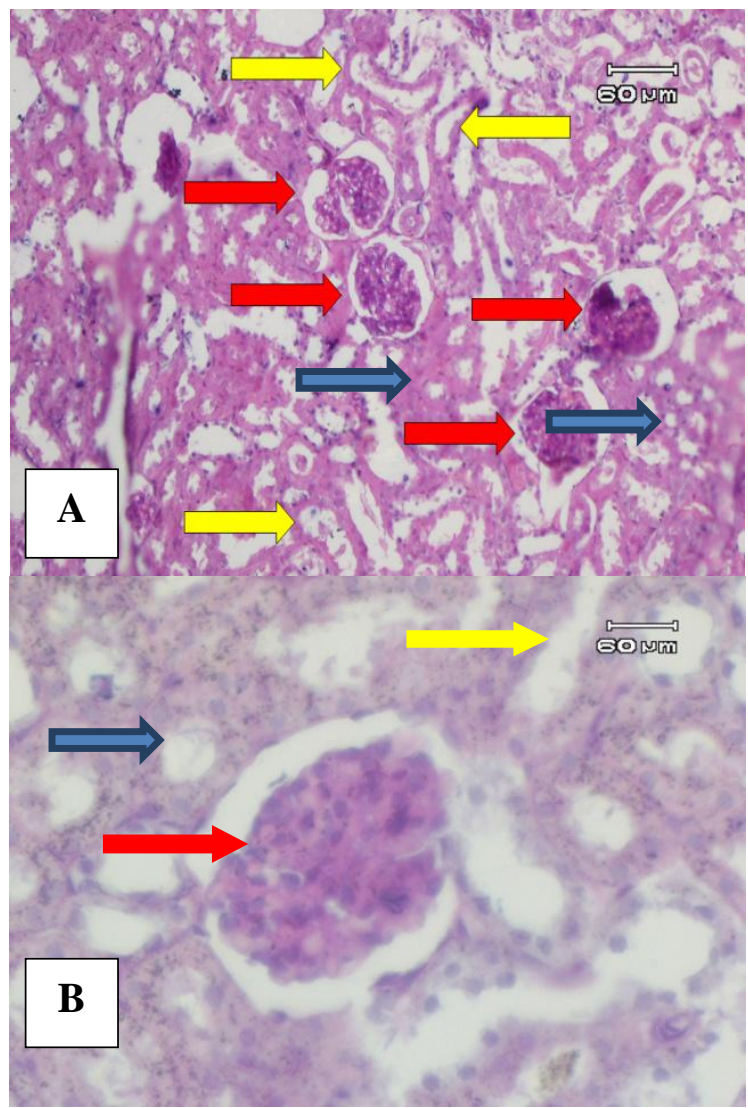

Gambar 1. Gambaran mikroskopik ginjal tikus wistar kelompok kontrol negatif. Tampak gambaran ginjal normal dengan glomerulus (panah merah), tubulus proksimal (panah biru) dan tubulus distal (panah kuning). A: pembesaran 10x10, B: pembesaran 10x20.

\section{Kelompok B}

Pada kelompok ini, gambaran histopatologik ginjal tikus wistar menunjukkan sebagian besar sel yang mengalami pembengkakan sel epitel tubulus dan terdapat cast hialin dalam lumen tubulus serta terdapat nekrosis (Gambar 2).

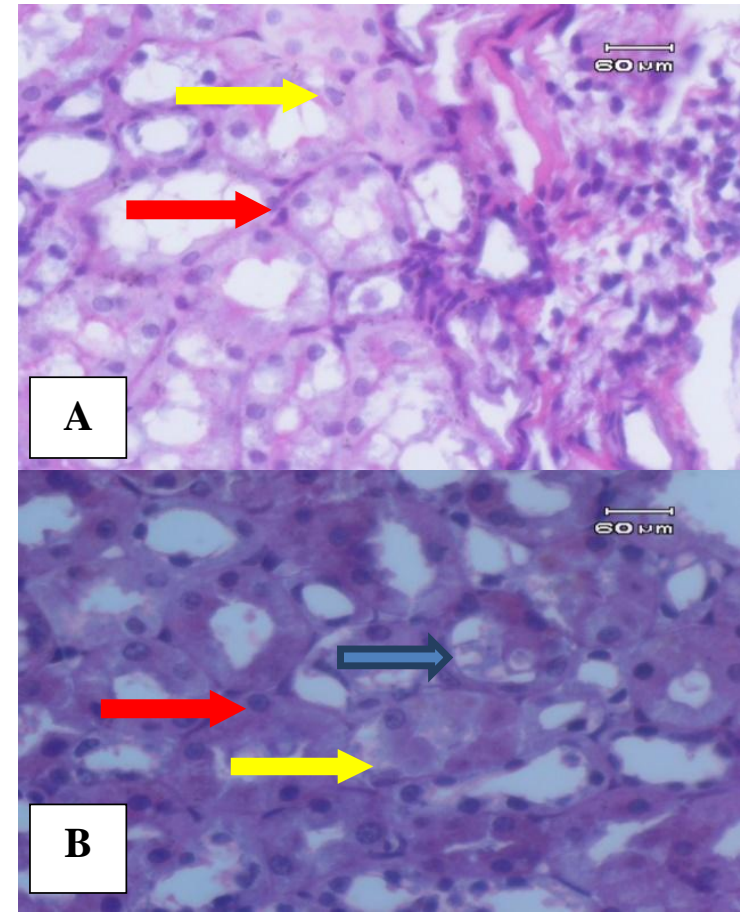

Gambar 2. Gambaran mikroskopik ginjal tikus wistar kelompok B. Tampak cast hialin (panah biru), sel epitel yang membengkak (panah merah), dan sel nekrosis (panah kuning) A: pembesaran 10x20, $\mathrm{B}$ dan $\mathrm{C}$ : pembesaran $10 \times 20$.

\section{Kelompok C}

Pada kelompok ini tampak tampak regenerasi ditunjukkan dengan sel yang membesar, pembuluh darah arteri dan pembengkakan sel epitel tubulus serta masih terdapat cast dan nekrosis (Gambar 3).

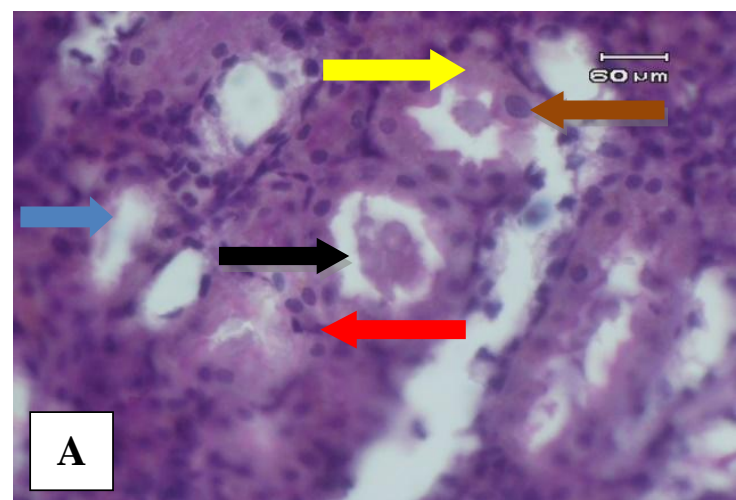

Gambar 3. Gambaran mikroskopik ginjal tikus wistar kelompok C. Tampak arteri (panah hitam), sel yang membesar (panah coklat) selsel yang mengalami pembengkakan (panah merah) dan cast (panah biru) serta nekrosis (panah kuning). Perbesaran 10x20 


\section{Kelompok D}

Pada kelompok ini tampak cast yang sudah semakin sedikit, sel epitel tubulus yang normal dan tidak terdapat nekrosis (gambar 4).

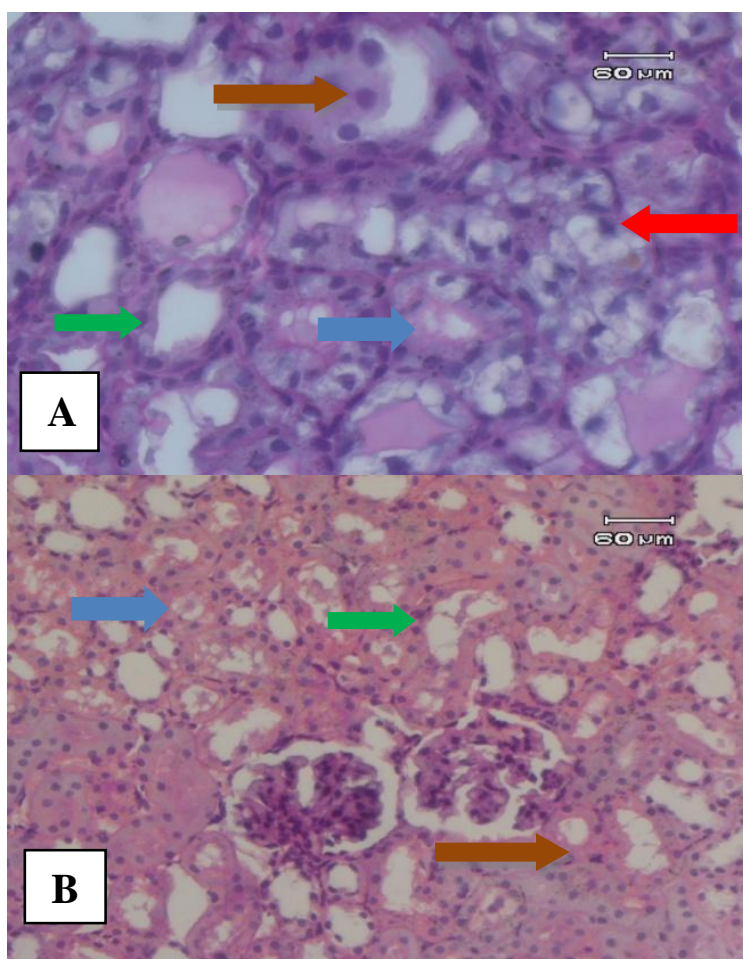

Gambar 4. Gambaran mikroskopik ginjal tikus wistar kelompok D. Tampak cast (panah biru), sel yang membesar (panah coklat), sel epitel yang normal (panah hijau) dan masih terlihat pembesaran sel (panah merah). A dan B: pembesaran 10x20.

\section{Kelompok E}

Pada kelompok ini tampak terdapat banyak cast, pembengkakan sel, dan juga terdapat sel radang limfosit serta nekrosis (gambar 5)

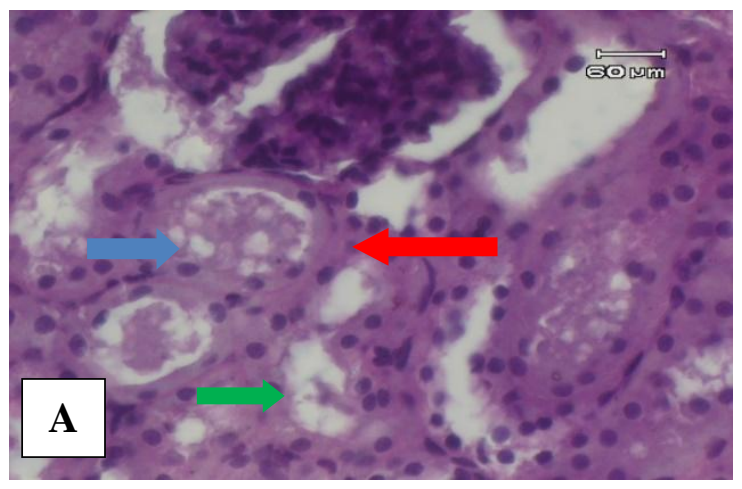

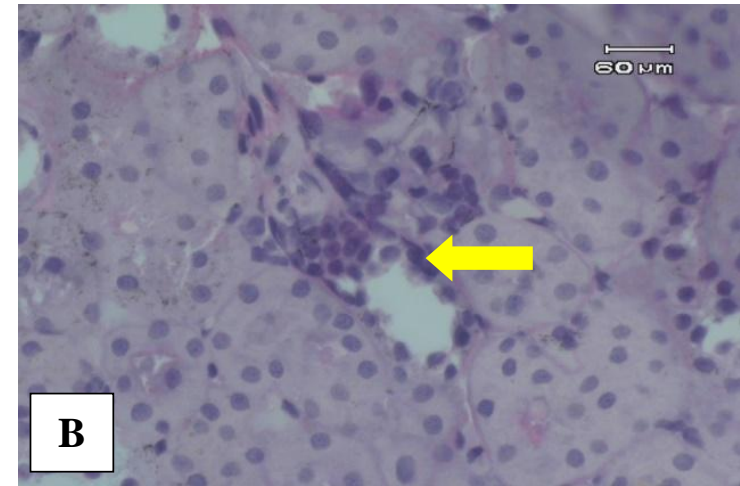

Gambar 5. Gambaran mikroskopik ginjal tikus wistar kelompok E. Tampak banyak cast (panah biru), pembesaran sel epitel (panah merah), nekrosis (pnah hijau) dan sel radang limfosit (panah kuning). A dan B : pembesaran $10 \times 20$

\section{BAHASAN}

Gentamisin tergolong antibiotika aminoglikosida yang sudah diketahui toksik terhadap ginjal. Akibat yang dapat ditimbulkan oleh agen nefrotoksik ini salah satunya adalah kerusakan tubulus ginjal, 8,9 dengan mengaktifkan protease yang menyebabkan cedera oksidatif epitel tubulus dan endotel kapiler disebabkan oleh karena pembentukan reactive oxygen species $(\mathrm{ROS}){ }^{7} \quad$ Pada penelitian ini gambaran mikroskopik antara kelompok kontrol dan perlakuan menunjukkan perbedaan yang cukup jelas. Struktur ginjal pada kelompok kontrol didapatkan normal sedangkan pada kelompok perlakuan yang di induksi gentamisin didapatkan sel-sel tubulus yang mengalami pembengkakan dan terdapat cast didalam tubulus. Dalam kelompok perlakuan yg hanya diberi gentamisin didapatkan sel yang mengalami nekrosis. Hal ini disebabkan karena konsentrasi gentamisin yang tinggi pada sel-sel epitel tubulus sehingga gentamisin mengakibatkan proses nekrosis melalui aktivasi jalur intrinsik secara langsung maupun tidak langsung pada mitokondria dengan mengganggu produksi ATP. Mekanisme tersebut mengganggu rantai pernapasan dan menghasilkan oksidatif stres akibat terjadinya peningkatan anion superoksida dan hidroksil radikal yang selanjutnya dapat mengakibatkan kematian sel. $^{10}$ 
Pada penelitian ini sel epitel tubulus yang nekrosis menunjukkan sel tidak berinti. Sel nekrotik tersebut terakumulasi menjadi cast pada bagian lumen. ${ }^{8,11}$ Pada penelitian ini cast terdapat pada kelompok tikus dengan perlakuan gentamisin selama 6 hari yang dilanjutkan dengan binahong $50 \mathrm{mg}$ dan $100 \mathrm{mg}$. Cast lebih banyak ditemukan pada kelompok yang hanya diberi gentamisin. Hal itu dikarenakan deplesi ATP oleh gentamisin sehingga terganggunya sitoskeletal epitel tubulus proksimal disertai perpindahan lokasi integrin dari permukaan basal kepermukaan apikal. Akibat perpindahan lokasi ini epitel tubulus terlepas dan menyebabkan reabsorbsi natrium menurun dan natrium di lumen tubulus meningkat disertai pembentukan cast oleh mikrovili sehingga terjadi obstruksi tubulus distal. ${ }^{7}$

Pada gambaran mikroskopik ginjal tikus wistar yang mendapatkan ekstrak binahong maupun pelet pasca induksi gentamisin didapatkan adanya sel-sel yang beregenerasi. Hal ini sesuai dengan teori yang disebutkan bahwa pemulihan fungsi ginjal dapat terjadi dengan menghilangkan agen penyebab., ${ }^{9,12}$ Selain itu, regenerasi sel epitel tubulus terjadi karena sel epitel tubulus ginjal termasuk sel stabil, yaitu mampu membelah diri dengan cepat dalam hal merespons cedera, namun beristirahat dalam keadaan normal. ${ }^{8,11}$ Pada penelitian ini juga, regenerasi sel ditemukan lebih banyak pada kelompok yang mendapatkan ekstrak binahong dibandingkan dengan kelompok yang hanya mendapat pelet (gambar 5). Proses regenerasi sel yang terjadi pada penelitian ini diduga berkaitan dengan peran dari ekstrak binahong. Ekstrak binahong mempunyai senyawa flavonoid yang berfungsi sebagai antioksidan, ${ }^{6}$ sehingga mengurangi jumlah lesi yang terbentuk dengan menambah jumlah antioksidan eksogen dalam tubuh untuk mengimbangi antioksidan endogen. ${ }^{13}$

Pada penelitian ini juga ditemukan bahwa kelompok yg mendapatkan ekstrak binahong $100 \mathrm{mg}$ (gambar 4) lebih baik di bandingkan dengan kelompok yang mendapatkan ekstrak binahong $50 \mathrm{mg}$ (gambar 3), yang ditandai dengan adanya cast yang sedikit dan terdapat banyak sel normal. Hal ini terjadi karena kemungkinan dosis antioksidan yang diberikan pada kelompok D lebih besar dibandingkan kelompok C.

\section{SIMPULAN}

Pemberian gentamisin injeksi dosis toksik yaitu $0,3 \mathrm{ml}$ setiap hari selama 6 hari menunjukkan nekrosis tubular akut (NTA. Regenerasi sel epitel tubulus ginjal lebih baik pada kelompok yang diberi ekstrak binahong dibandingkan kelompok yang hanya diberi pelet (regenerasi fisiologi). Pemberian binahong dosis $100 \mathrm{mg}$ lebih baik dibandingkan dosis $50 \mathrm{mg}$.

\section{SARAN}

1. Perlu dilakukan pemeriksaan kadar kreatinin untuk mengetahui kerusakan ginjal yang terjadi pada beberapa kelompok perlakuan.

2. Pada penelitian berikutnya perlu menambah jumlah dosis dan periode pemberian ekstrak binahong.

\section{DAFTAR PUSTAKA}

1. Davis CP. Creatinin blood test. 2015 jan 13 [cited 2015 oct 8]. Available from : http://www.medicinenet.com/creatini ne_blood_test/article.htm

2. Chambers HF. The aminoglicoside, In: Hardman JG, Limbird LE, eds. Goodman \& Gilman's the Pharmacological Basis of Therapeutics. 10th ed. New York: McGraw-hill; 2001.p.1219-38

3. Syarif A, Setiawati A, Muchtar HA, Arif A, Tirza D, Bahry B, et al. Farmakologi dan terapi. Edisi ke-4. Jakarta:Gaya baru; 2001.p.667

4. Katzung BG. Basic \& clinical pharmacology. $10^{\text {th }}$ edition. United states: Lange Medical Publication

5. Ratna D. Antioxydant actifity of flavonoid from anredera cordifolia (Ten) steenis leave. International research journal of pharmacy. Jakarta: Fakultas farmasi universitas pancasila. 44(3): h.122-34 
6. Wismaji G. Pengaruh jus daun binahong (Anredera corifolia (Ten) Steenis) Terhadap Kadar Kreatinin Darah Mencit (Mus Musculus) Swiss webster. Universitas Muhammadiyah Surakarta: 2012 p.2

7. Sondakh PLN. Gambaran Histopatologi Ginjal Tikus Wistar (Rattus norvegicus) yang Telah Diinduksi Gentamisin Terhadap Pemberian Jahe (Zingiber officinale) [skripsi]. Manado: Fakultas Kedokteran Universitas Sam Ratulangi; 2012

8. Alpers CE, Chang A. The Kidney. In: Kumar V, Abbas AK, Aster JC, editors. Robbins and Cotran pathologic basis of disease. 9th ed. Philadelphia: Saunders, 2015. pp.897957.

9. Istiantoro YH, Gan VHS. Aminoglikosid. Dalam: Gunawan SG, Nafrialdi RS, Elysabeth, editors. Farmakologi dan Terapi. Ed 5. Jakarta: Balai Penerbit FKUI; 2008. p.705-17.
10.Lopez-Novoa JM, Yaremi Q, Vicente L, Morales AI, Lopez-Hernandez FJ. New Insights into the mechanism of aminoglycoside nephrotoxicity: an integrative point of view. Kidney International 2011;79:33-45

11.Cotran RS, Rennke H, Kumar V. Buku Ajar Patologi. Edisi 7. Jakarta: Penerbit Buku Kedokteran EGC; 2007

12.Chambers HF. Aminoglycocides \& spectinomycin. In: Katzung BG, ed. Basic \& Clinical Pharmacology. 11th ed. New York: McGraw-Hill Medical; 2009

13.Asmariyati YD, Busman H, Susantiningsih T, Suasanti. Protective effect of binahong leaf extract against ethanol, induced proximal tubule renal hstopatological features of Sprague dawley strains white rats. [jurnal]. Fakultas kedokteran Universitas Lampung.2014. 